\title{
A strategy to deal with water crisis under climate change for mainstream in the middle reaches of Yellow River
}

\author{
Xiao-jun Wang • Jian-yun Zhang • Rui-min He • \\ EIMahdi Amgad • EISawah Sondoss • Man-ting Shang
}

Received: 27 August 2010 / Accepted: 30 November 2010

(C) Springer Science+Business Media B.V. 2010

\begin{abstract}
Our planet is increasingly threatened by degradation in water quantity and quality due to climate change, population growth and development pressures. Water shortage is one of the most challenging environmental problems to humankind in the $21 \mathrm{st}$ century under the changing climate. Water shortages and scarcity escalate risks to food security and economic viability. For decades, water management has been dominated by supply oriented paradigm of expanding the capacity of accessible water (e.g. building dams). While large scale infrastructure projects provided effective solutions for chronic water crises in the past, they have come at expensive, irreversible and delayed ecological, economic and social costs. As more questions are raised concerning over reliance on infrastructure solutions, discussions about a sustainable future suggest a greater focus on the demand side of the equation is needed. In this paper, we use multi-recursive and runoff coefficient analysis methods to analyze the annual runoff of the mainstreams (Kuye River, Tuwei River, Wuding River and Jialu River) in the middle reaches of Yellow River. The main objective is to estimate the impacts of climate change and human activity on water resources in the study area and test the potential of water demand management to lessen the gap between supply and demand. Results show remarkable drop in the average annual runoff as a combined effect of climate change and human activity. Moreover, results show that human activities are the direct reason for the changes of river runoff, and the proportion of human activities account the biggest is Wuding river, next is Kuye river, Jialu river is smallest, these changes lead to the decrease of river runoff, and even drying up in recent
\end{abstract}

X.-j. Wang $(\bowtie) \cdot$ J.-y. Zhang $\cdot$ R.-m. He $\cdot$ M.-t. Shang

Nanjing Hydraulic Research Institute, Nanjing 210029, China

e-mail: nhri501@yahoo.com.cn

X.-j. Wang • J.-y. Zhang $\cdot$ R.-m. He $\cdot$ M.-t. Shang

Research Center for Climate Change, Ministry of Water Resources, Nanjing 210029, China

E. Amgad

Climate and Water Division, Bureau of Meteorology (BOM), Melbourne, Australia

E. Sondoss

Integrated Catchment Assessment and Management (iCAM), Australian National University, Canberra, Australia 
years. This result highlights the importance of using WDM to diminish the increasing gap between demand and supply. Motivated by this, the paper presents a comprehensive framework for implementation WDM in the middle reaches of Yellow River. The framework includes a wide range of instruments: legislative, economic, technological and educational. The core step of the framework, collaboration among water planners, water service providers and end-users lies as an essential mechanism for achieving long term trade-offs between ecological and socio-economic water needs.

Keywords Climate change · Water Demand Management (WDM) · Yellow River · Regression analysis

\section{Introduction}

Climate change represents serious challenge to natural resource management including water management (Elmahdi 2008; Medellín-Azuara et al. 2008; Stephenson 1999). The combined impacts of climate change and urban development impose severe risks to the hydrological cycle and other related natural phenomena whose effects extend far beyond human experience and knowledge (Elmahdi et al. 2009a, b; Middelkoop et al. 2001; Chen and Xu 2005; Akhtar et al. 2008; Bates et al. 2008; Zhang et al. 2007). This includes risks to water security, river function and related economic and ecological systems (Wang et al. 2010a, b; Ren et al. 2002; Fang et al. 2007; Chen and Xu 2005; Ma et al. 2008).

This research focuses on water management in the Yellow River (YR), or Huanghe. The YR is the second longest river in China $(5464 \mathrm{~km})$, with headwaters originating in the Tibet Plateau and flowing eastward to the Bohai Sea. The river carries out an important socio-economic function for China by supporting food production, mining activities chemical and oil industry. Because of the rapid economic growth in the region, water demand for agriculture, industry and households have increased significantly. This has caused an increasing gap between water supply and demand. One of the options to meet increasing demand is to transfer water from south from Yangtze River to the Yellow River (Liu et al. 2006; Yu 2006). Whereas this option may secure water supply for some time, it has expensive economic and environmental costs (Butler and Memon 2006; Stephenson 1999). Therefore, Water Demand Management (WDM) provides a more effective approach in terms of minimizing ecological and socioeconomic costs associated with intensive infrastructure (Wang et al. 2009a, b; Butler and Memon 2006; Savenije and van der Zaag 2002; Stephenson 1999).

In this paper, we analyze annual runoff of mainstream in the middle reaches of Yellow River based on the long-time series data from 1956 to 2005 and test the water demand management as strategy to augment the water supply and lessen the gap between demand and supply under climate change. The paper tests the tendency of annual runoff in the past 50 years by Mann-Kendall non-parameter statistical method. The main assumption is that climate change and human activities are the major driving forces to the changes in runoff in the Kuye River, Tuwei River, Wuding River and Jialu River (show in Fig. 1). Also, the paper presents a comprehensive framework of planning implementation water demand management in middle reaches of Yellow River. The framework includes a wide range of instruments: legislative, economic, technological and educational. At the core of the framework, Collaboration among water planners, water service providers and end-users lies as an essential mechanism to achieve best long-term outcomes considering the triple bottom line (ecological and socio-economic). 


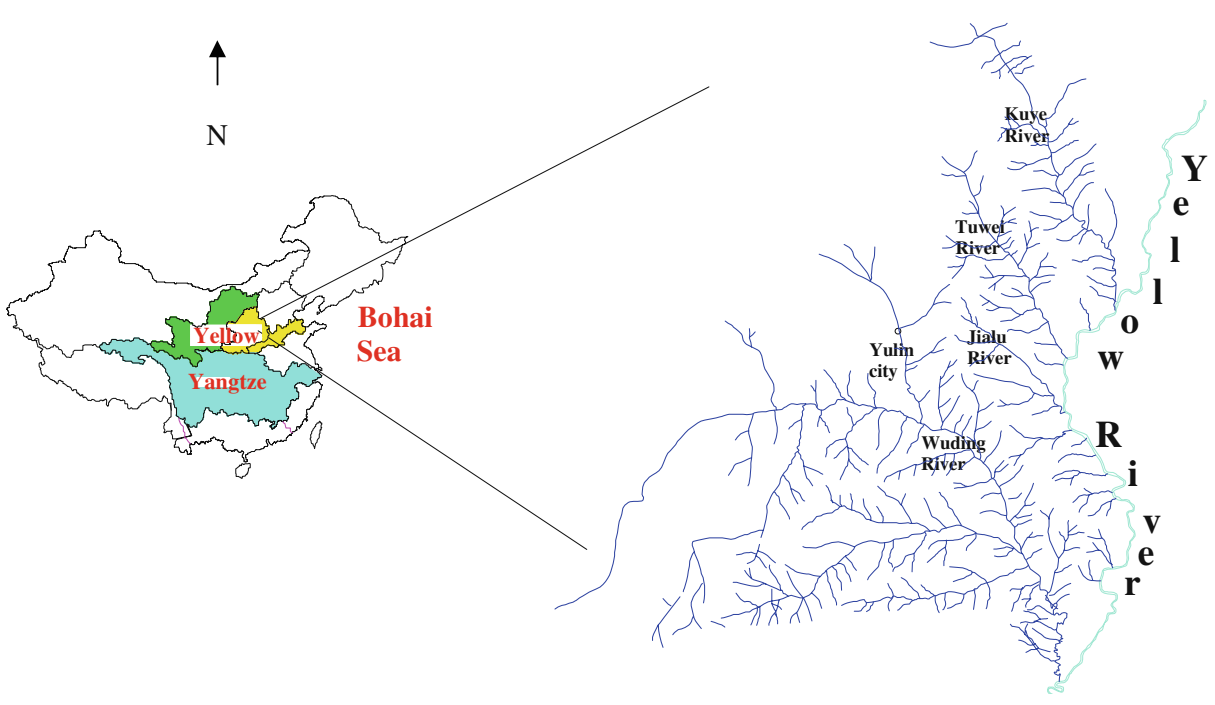

Fig. 1 Sketch map of the study area

\section{Methodology}

\subsection{Data}

In this paper, Annual precipitation and runoff data of four controlling stations in mainstream from 1956 to 2005 were collected and analyzed. And these stream flow gauges administered by National Climate Center, Ministry of water resources, and the Yellow River Water Conservancy Commission respectively. Data about the socioeconomic and hydrological engineering activities were also collected and analyzed. Table 1 lists the basic information about the four main controlling stations of the four rivers (Table 2).

\subsection{Multiple regression model/analysis}

The analysis is based on the premise that the runoff generation process is governed by precipitation and human activity. The assumption is that human activity and climate change are independent factors. We know that if there is human activities and climate change impact, the

Table 1 The main controlling stations of the main river in the middle reaches of Yellow River

\begin{tabular}{lllllll}
\hline NO & River name & $\begin{array}{l}\text { Hydrological } \\
\text { station name }\end{array}$ & $\begin{array}{l}\text { Location } \\
\text { of the station }\end{array}$ & \begin{tabular}{l} 
Coordinate location \\
\cline { 4 - 5 }
\end{tabular} & & Water collecting area $\left(\mathrm{km}^{2}\right)$ \\
\hline 1 & Kuye River & Wenjiachuan & Shenmu country & $110^{\circ} 45^{\prime}$ & $38^{\circ} 26^{\prime}$ & 8645 \\
2 & Tuwei River & Gaojiachuan & Shenmu country & $110^{\circ} 29^{\prime}$ & $38^{\circ} 15^{\prime}$ & 3253 \\
3 & Jialu River & Shenjiawan & Jia country & $110^{\circ} 29^{\prime}$ & $38^{\circ} 02^{\prime}$ & 1121 \\
4 & Wuding River & Baijiachuan & Qingjian country & $110^{\circ} 25^{\prime}$ & $37^{\circ} 14^{\prime}$ & 29662 \\
\hline
\end{tabular}


accumulation curves of the observed runoff will have a change points. The natural point (without change) has no influence of human or climate change impacts in the accumulation curves of the observed runoff. By using this natural point we build the regression equations between precipitation and runoff through multi-recursive analysis. For example,

$$
W=a_{0}+a_{1} P_{1}+a_{2} P_{2}+a_{3} P_{3}+a_{4} P_{4}+a_{5} P_{5}
$$

In which, $\mathrm{W}$ represents the runoff of the main hydrological stations $\left(10^{4} \mathrm{~m}^{3}\right), P_{1}, P_{2}, P_{3}, P_{4}$, $P_{5}$ represent average annual precipitation as observed from the meteorological stations or hydrological station in the river watershed (mm), $\alpha_{1}, \alpha_{2}, \alpha_{3}, \alpha_{4}, \alpha_{5}$ is partial regression coefficients of $W$ to $P_{1}, P_{2}, P_{3}, P_{4}, P_{5}$, respectively.

Regression equations are used to estimate average runoff. This represents the natural runoff generated without the impact of human activity, including measured runoff. Then, the difference between the estimated and observed values for the period 1956-2005 account for the impact of human activities on the runoff, as calculated by the following,

$$
\begin{gathered}
D W_{T}=W_{H N}-W_{H R} \\
\Delta W_{C}=W_{B}-W_{H R} \\
D W_{H}=D W_{T}-D W_{C} \\
\eta_{H}=\frac{\Delta W_{H}}{\Delta W_{T}} \times 100 \% \\
\eta_{C}=\frac{\Delta W_{C}}{\Delta W_{T}} \times 100 \%
\end{gathered}
$$

Where, $D W_{T}$ is the amount of runoff change $\left(10^{4} \mathrm{~m}^{3}\right), D W_{H}$ is the amount influenced by human activity $\left(10^{4} \mathrm{~m}^{3}\right), D W_{c}$ is the amount influenced by climate change $\left(10^{4} \mathrm{~m}^{3}\right), W_{B}$ is the natural runoff before human activity during the baseline $\left(10^{4} \mathrm{~m}^{3}\right), W_{H R}$ is the gauged discharge during human activity period $\left(10^{4} \mathrm{~m}^{3}\right), W_{H N}$ is the natural discharge during human activity period $\left(10^{4} \mathrm{~m}^{3}\right), \eta_{H}, \eta_{C}$ is the proportion influenced by human activity, climate change (\%), respectively (Wang et al. 2006, 2008). (See Fig. 2).

\subsection{Runoff coefficient method}

Discriminating the impacts of climate change and human activities on the runoff are a problem that puzzled researchers for a long time (Wang et al. 2008; Chen et al. 2007). In this paper, we also use the runoff coefficient method to calculate the impact of precipitation and human activity (Li and Feng 2007).

In which, we define that

$$
D=W / P
$$

Where D is runoff coefficient, which is a ratio of rainfall to runoff rate. Using the runoff coefficient, we can calculate how much water processed during the rainfall. $\mathrm{P}$ is 


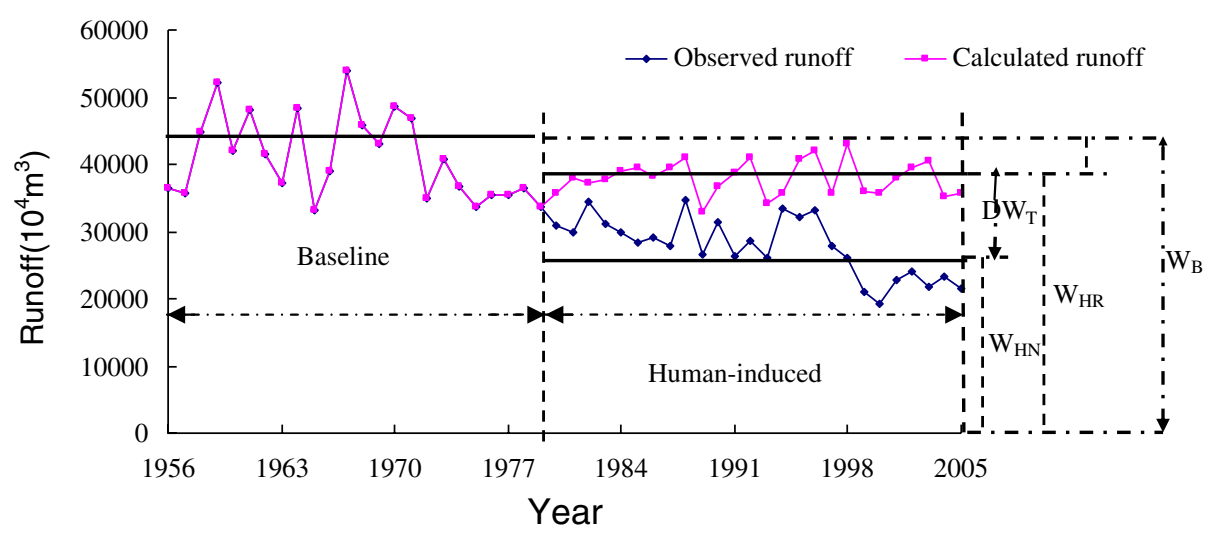

Fig. 2 Impacts of climate change and human activity on runoff in Tuwei River

precipitation of the whole watershed $(\mathrm{mm}), \mathrm{W}$ is the average annual runoff $\left(10^{4} \mathrm{~m}^{3}\right), W=D$. $P$. Some formula derived form the equation can be expressed as:

$$
\begin{gathered}
W_{1}=D_{1} \cdot P_{1} \\
W_{2}=D_{2} \cdot P_{2} \\
\Delta W=W_{1}-W_{2}=\frac{\left(P_{1}+P_{2}\right)}{2}\left(D_{1}-D_{2}\right)+\frac{\left(D_{1}+D_{2}\right)}{2}\left(P_{1}-P_{2}\right)=\bar{P} \cdot \Delta D+\bar{D} \cdot \Delta P
\end{gathered}
$$

Where $W_{1}, W_{2}, P_{1}, P_{2}, D_{1}$ and $D_{2}$ are average values of two adjacent periods of runoff, precipitation and runoff coefficient, respectively. If $\mathrm{P}$ remains unchanged, $\Delta W=\bar{P} \cdot \Delta D$ shows the human activity impact. If $D$ remains unchanged, then $\Delta W=\bar{D} \cdot \Delta P$ shows the climate change (precipitation) impact. Using these methods gives us a rough indication of the direction and magnitude of the combined effect that climate change and human activity have on the average runoff in the middle reaches of Yellow River.

\section{Results}

According to the hydrological data of annual runoff from 1956 to 2005, the Mann-Kendall test shows that there is an obvious dropping tendency among different rivers (show as Table 2). Tuwei River and Jialu River is the most significant, the $U(R)$ is $-7.54,-7.27$, next is Wuding River, $U(R)=-5.88$, the last is Kuye River, only -4.86 (Wang et al. 2008).

Table 2 Results of Mann-Kendall non-parameter for tendency test

\begin{tabular}{llll}
\hline River name & Hydrological station name & Mann-Kendall test & Tendency (Significance level $p=5 \%$ ) \\
\hline Kuye River & Wenjiachuan & -4.86 & Significant \\
Tuwei River & Gaojiachuan & -7.54 & Significant \\
Jialu River & Shenjiawan & -7.27 & Significant \\
Wuding River & Baijiachuan & -5.88 & Significant \\
\hline
\end{tabular}




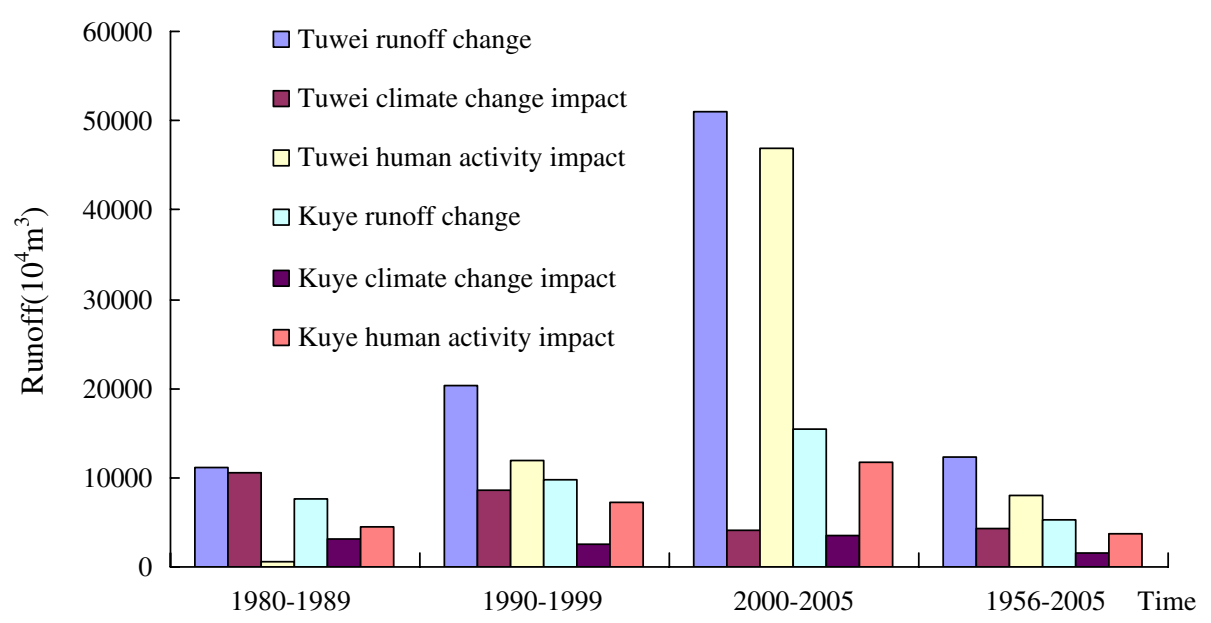

Fig. 3 The estimated average annual runoff as affected by climate change and human activity in Kuye River, Tuwei River

We use multivariate linear correlation analysis to capture the relationship between runoff and precipitation of the main river in Kuye River and Tuwei River. Using multiple regression analysis, the change in annual runoff resulting from climate change and human activity can be estimated (See results in Fig. 3).

Results show that the influence of human activity has a monotonically increasing trend in Kuye River and Tuwei River in the past 50 years from 1956 to 2005, along with observed temporal variations in the relative influence of climate change and human activity. For example, in Kuye River, climate change (precipitation) played an important role in runoff reductions through the period 1980-1989, with proportional increase up to $94 \%$.

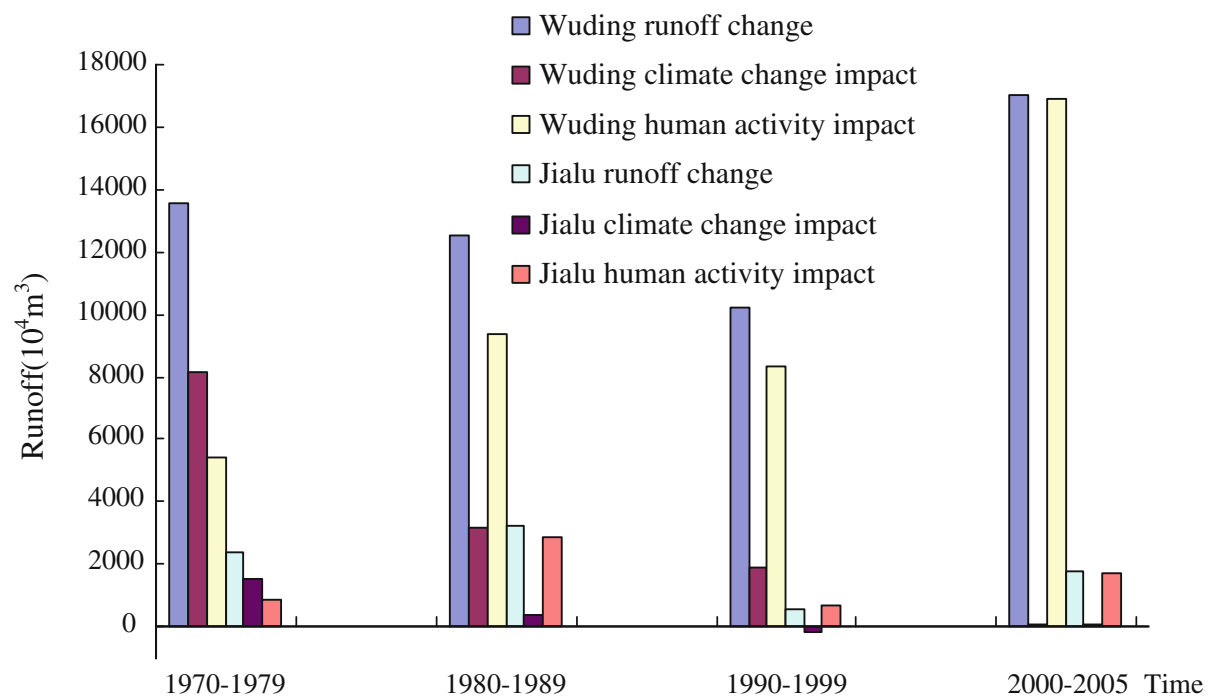

Fig. 4 The estimated average annual runoff affected by climate change and human activity in Jialu River, Wuding River 
Through the period of 2000 to 2005 human activity became the major driver for runoff reductions, during, with proportion up to $92 \%$. For Jialu River and Wuding River, we use runoff coefficient method to discriminate the impacts of climate change and human activities on the annual runoff, results in the Fig. 4.

Results show that human activity, including industrial and agriculture activities, is also the main factor of runoff changes in the two rivers, and along with the time periods, especially in recent decade, To further examine this result, we also investigate the water consumption in Yulin city in the middle reaches of Yellow rivers in the past years as shown in Fig. 5. We can get that human need for water supply is always increasing in the past years, and because of the consumption of surface flow, the groundwater supply is always in significant increasing.

\section{Water Demand Management (WDM): a strategy to deal with water crisis under climate change}

\subsection{Water demand management}

Demand Management (DM) is defined as the development and implementation of strategies that aim to influence demand, in order to achieve efficient and sustainable use of a scarce resource (Stephenson 1999; Gumbo 2004). Policy and decision-makers need better understanding of what/how demand management strategies could assist in the short- to medium-term. Theory of Demand Management has been widely used in the field of transportation, energy, power industry, et al., as to water resources; Water Demand Management (WDM) is regarded as potential sustainable solution to meet future needs (Elmahdi et al. 2006; Stephenson 1999; Kolokytha and Mylopoulos 2004; Gumbo 2004; Gumbo et al. 2005). It is an integral and indispensable part of Integrated Water Resource Management, through adaptation and implementation of a wide range of technical, planning, economic, regulatory and consultative instruments, to improve the efficient and effective use of water supply resources. WDM has been widely implemented in many areas around world, such as South Africa, Australia (Elmahdi and McFarlane 2008; Butler and Memon 2006; Elmahdi et al. 2005???), Middle East (Elmahdi et al. 2009a, b;

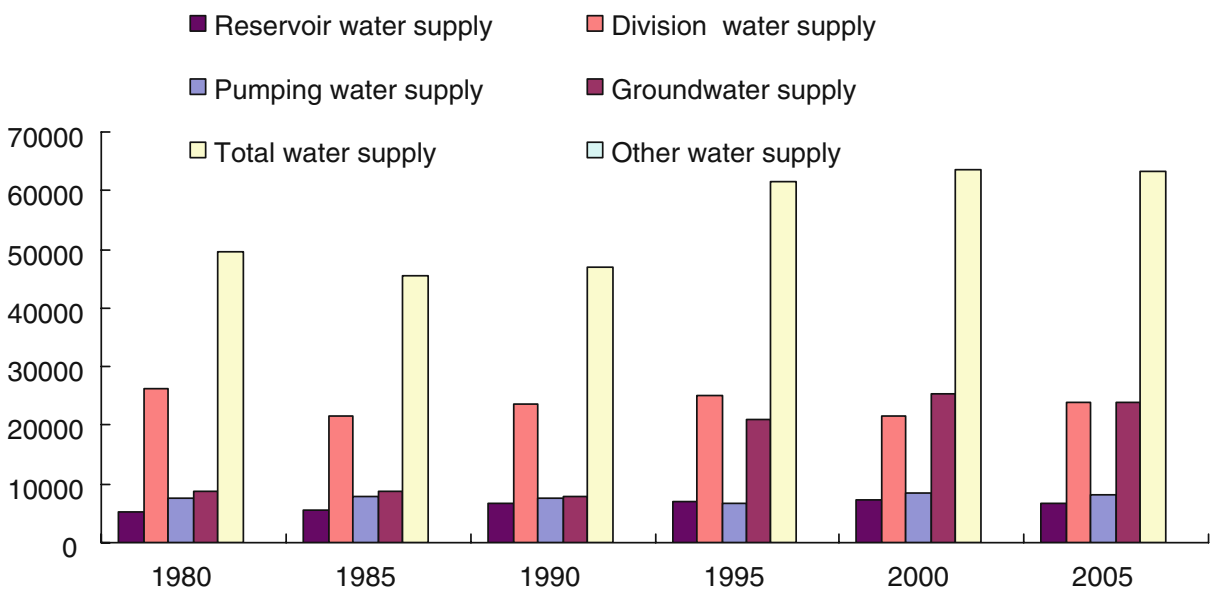

Fig. 5 Water supply in Yulin city in the middle reaches of yellow river 
Butler and Memon 2006) and Canada (Butler and Memon 2006; Brooks and Peters 1988).

\subsection{Framework of planning implementation WDM in middle reaches of Yellow River}

From the above discussion, it is clear demand management can reduce the gap between in supply and demand. As mentioned previously increasing demand is the main reason for water crisis in the middle reaches of Yellow River. The debate in China suggests that through water transfer from south to north to solve the problem, which means water from Yangtze River could be diverted to the Yellow River, but some of the research has been demonstrated that benefits of Water Demand Management (WDM) include lower costs, reduction serves economic and resource conservation as compared to new supply schemes (Wang et al. 2009a, b; Butler and Memon 2006; Savenije and van der Zaag 2002; Stephenson 1999). Therefore, it is necessary to carry out WDM in middle reaches of Yellow River for sustainable water management. Now, the important question is: what is the framework that can be used to implement WDM (See Fig. 6).

Tools and techniques to promote demand management can be classified in many ways but the following four categories are convenient (Rosegrant 1997). None of the measures are in reality as simple as they appear in the list below, even for surface water and, in almost all cases; they are even more complex for groundwater. As in the study area, we also take some of the measures as follows:

a) Institutions and laws:

Supply and demand systems for water always exist within a set of water rights, land rights, environmental rules, social and civil institutions, and legal regimes. Some are formal and others informal; some modern and others traditional; some international and others local, so it is difficult to implement. At present, China has adopted four important legislation for water management, Water Law (adopted in 1988 and revised in 2002), Law on Water Pollution Control (adopted in 1984), Soil and Water Conservation Law (adopted in 1991), Flood Control Law (adopted in 1997). Those four laws provides a comprehensive framework for water resources management, they are fundamental laws for water resource utilization, protection, management and flood control in China (Zhang 2005). Besides, Yellow River commission also have other laws and regulations for water management, but there is still no legislation made according with the four rivers, they are still managed by YRCC, and so it is necessary to manage water resource integrated by the basin as soon as possible. And with the implementation of the strictest water resources management system, total water demand will be controlled under the water abstraction permits system, so in the future, institutions in these four Rivers considered in this study are water sharing plan, environmental flow, water trading rules and the groundwater sharing plan.

b) Market-based measures:

This is the world of water prices and tariffs, and of water subsidies, both of which appear in a variety of forms, these measures are widely used in all WDM programme all over the world (Stephenson 1999; Rogers et al. 2002; Savenije and van der Zaag 2002). But in these four Rivers, water price for agriculture are calculated by the area, there is still don't have other measures for metering, so the water price is much lower than the cost of water supply, and the gap is substantial, especially in the agriculture sector. Besides, water price in these rivers always set at a fixed rate without considering the variation of water availability during different seasons. So it is reforming the water 


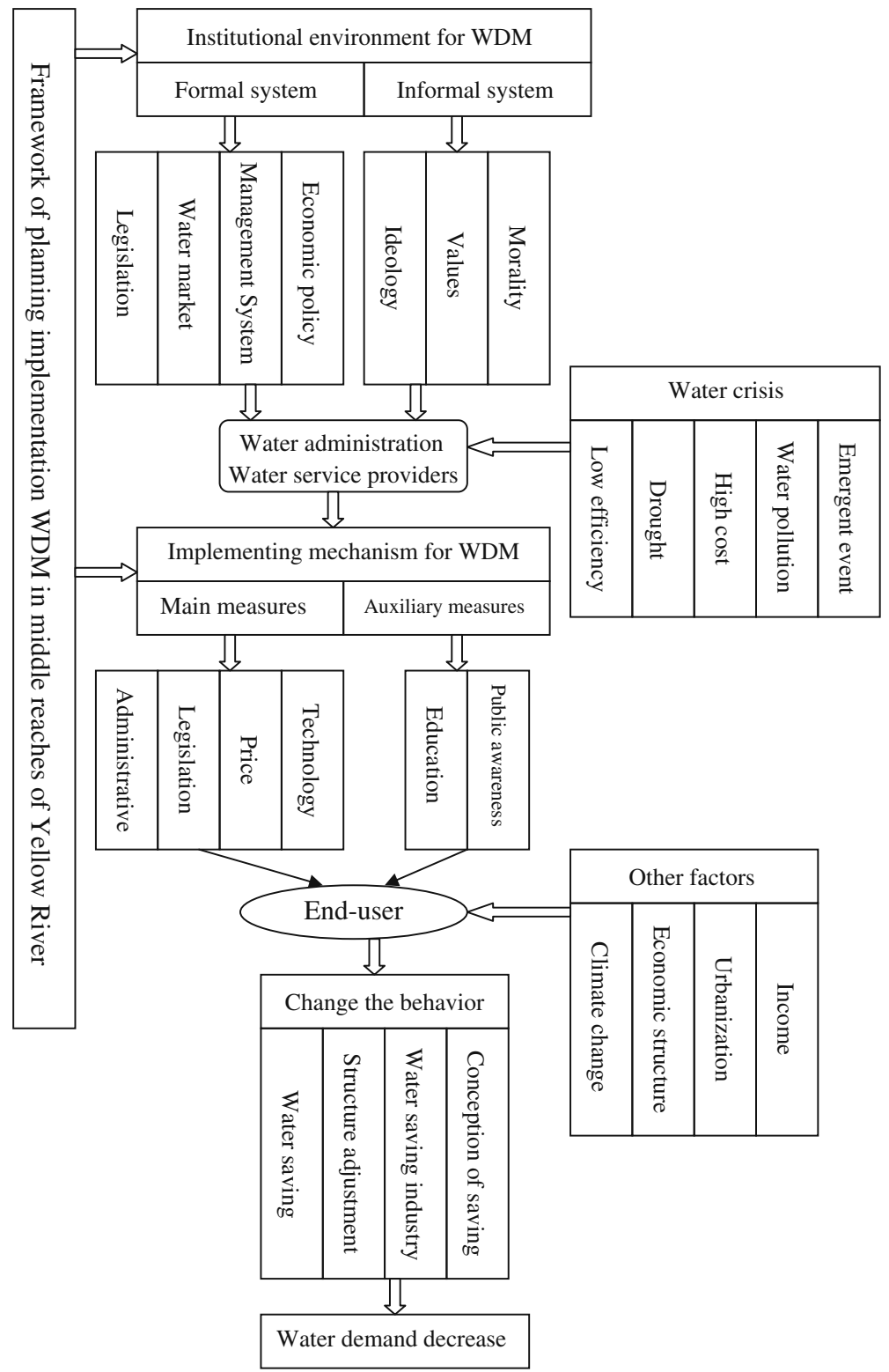

Fig. 6 Framework of planning and implementation of WDM in middle reaches of Yellow River

price system, this will be necessary for water saving. Under the reforming water price system and water abstraction permitting system, access to water resources by an individual or unit is regulated with permission, these who have the right of water abstraction permits are required to submit an Water Use Plan to their administering authority, and then the administering authority allocate the actual amount available to the permit holder for the year with the actual water supply under the seasonal changes. Then the holders can trading the water permits between different sectors, this have 
successful experience in Tuwei River in the past year. And in the future, it is necessary to set up the water right market and then to improve water use efficiency for the whole basin.

c) Non-market measures:

An enormous variety of non-financial measures, including education and advocacy, can be used to manage water demand (Brooks and Peters 1988; Elmahdi and McFarlane 2010). Although regulations have a bad name, they are often both appropriate and efficient for managing water demand. Public awareness and education programs aim to influence water users' decisions and behaviours. In the past, China used to provide water almost free of charge as water was regarded as a basic necessity, and a relatively cheap and abundant resource. As communities' demand for water grows, it is necessary to change the perceptions that people have about water. Human perceptions are influenced by a complex constellation of socio-cultural drivers that are difficult to manage and change. Education programs needs to target children to achieve long-term change in attitude towards water use.

d) Direct intervention:

Governments and water authorities can, of course, intervene directly by providing services, installing consuming or conserving equipment, fixing leaks by lining canals, adjusting pressure, providing drainage, etc. More fundamentally, they can also affect, if not control, land use by their decisions on the location and quality of water and soil, which is of course why these decisions are so politically sensitive.

\section{Conclusions}

1. The Yellow river is under the increasing pressures of climate change effects and urban development. The objective of this paper is to estimate the impacts of climate change and human activity on water supply in the study area and test the potential of water demand management to lessen the gap between supply and demand. We use multirecursive and runoff coefficient analysis methods to analyze the annual runoff of the mainstreams through the period 1956-2005. Results show remarkable drop in the average annual runoff as a combined effect of climate change and human activity.

2. Moreover, results show that traditional infrastructure solutions are not economically and environmentally sustainable. Therefore, water management need to move more towards demand management approaches. In this paper, we present a framework for implementing WDM in middle reaches of Yellow River. The framework includes a set of legislative, market-based and communication mechanisms. We stress that effective implementation of this framework relies on the ongoing collaboration stakeholder groups (e.g. managers, users, service providers) in order to make trade-offs make trade-offs that address the ecological, social and economic values of stakeholders. Whereas the framework is developed for the context of YR, it can be transferred to other river basins.

However, some questions are worthy of consideration. (1) water crisis is a complex problem, in this paper, we connect decreasing annual runoff as the main factor, other factors such as water demand, water shortage should also be considered; (2) The driving factors for runoff change are also a complex problem, both human activity and climate change should take into consideration, and we try to use those two methods to discriminate the amount of climate change and human activity, but those models used annual runoff for calculating, and this is also 
of a data of average in the past years, don't consider the extreme events such as flood and drought, so the results should verified in the future changing climate; (3) we only give a framework for water demand management framework, there may be many problems for WDM to carry out, besides, WDM should take full consideration of poverty and human rights in the future, so it is necessary to get further research.

Acknowledgements Authors are grateful to the National Basic Research Program of China (No. 2010CB951104) and Non-profit Industry Program of the Ministry of Water Resource of the People's Republic of China (No. 200801001) for their financial support of the research. Special thanks to the anonymous reviewers and editors for their constructive review. Australian authors would like to thank the Australian Bureau of Meteorology (BOM) and the Australian National University (ANU).

\section{References}

Akhtar M, Ahmad N, Booij MJ et al (2008) The impact of climate change on the water resources of HindukushKarakorum-Himalaya region under different glacier coverage scenarios. J Hydrol 355:148-163

Bates BC, Kundzewicz ZW, Wu S, Palutikof JP (eds) Climate Change and Water. Technical Paper of the Intergovernmental Panel on Climate Change. IPCC Secretariat. Geneva. 2008

Brooks D, Peters R (1988) Water: The potential for demand management in Canada. Science Council of Canada, Ottawa

Butler D, Memon FA (2006) Water demand management [M]. IWA Publishing, London

Chen YN, Xu ZX (2005) Plausible impact of global climate change on water resources in the Tarim River Basin. Sci China Ser D, Earth Sciences 48(1):65-73

Chen L, Liu C, Li Y (2007) Impacts of climatic factors on runoff coefficients in source regions of the Huanghe River. Chin Geogr Sci 17(1):47-55

Elmahdi A (2008) Water Banking -Landuse Approach to Improve River Productivity and Environmental Performance. National Nile Basin Commission Journal Vol1, (Invited paper)

Elmahdi A, McFarlane D (2008) A decision support system for a groundwater system affected by climate change, landuse and extraction. World Water week, Stockholme, August 2008

Elmahdi A, McFarlane D (2010) Integrated multi-agency framework MAF: sustainable water resource management. Accepted at Journal of Water Resources Planning and Management

Elmahdi A, Malano H, Etchells T, Khan S (2005) System dynamics optimisation approach to irrigation demand management. In Zerger A, Argent RM (eds) MODSIM 2005 International Congress on Modeling and Simulation. Modeling and Simulation Society of Australia and New Zealand, December 2005, pp. 196-202. ISBN: 0-9758400-2-9. http://www.mssanz.org.au/modsim05/proceedings/papers/ elmahdi.pdf

Elmahdi A, Kheireldin K, Hamdy A (2006) GIS and Multi-Criteria Evaluation: Robust Tools for Integrated Water Resources Management. 2006 International Water Resources Association IWRA, Vol 31. No. 4 Dec 2006

Elmahdi A, Shahkarami N, Morid S2, Massah Bavani AR (2009) Atmospheric- Ocean General Circulation Models (AOGCMs)- Uncertainty and Risk Assessment Of Future Water Demand. National Nile Basin Commission Journal Vol2, (invited paper)

Elmahdi A, ElGafy I, Kheireldin K (2009) Global warming-water Shortage and Food Security future planning interaction: System Analysis Approach (WBFSM). WRM-2009 Water Resource Management Malta Sep 2009

Fang C-L, Bao C, Huang J-C (2007) Management implications to water resources constraint force on socioeconomic system in rapid urbanization: a case study of the Hexi Corridor, NW China. Water Resour Manage 21:1613-1633

Gumbo B (2004) The status of water demand management in selected cities of southern Africa. Phys Chem Earth 29:1225-1331

Gumbo B, Forster L, Arntzen J (2005) Capacity building in water demand management as a key component for attaining millennium development goals. Phys Chem Earth 30:984-992

Kolokytha EG, Mylopoulos NA (2004) Evaluating demand management aspects of urban water policy. The city of Volos Case, Greece. Water Air Soil Pollut 4:263-277 
Li J, Feng P (2007) Runoff variations in the Luanhe River Basin during 1956-2002. J Geog Sci 17(4):339350

Liu CM, Yang ST, Sun R (2006) Study on hydrological components in the Yellow River basin based on RS/ GIS. Yellow River Press, Zhengzhou

Ma ZM, Kang SZ, Zhang L (2008) Analysis of impacts of climate variability and human activity on stream flow for a river basin in arid region of northwest China. J Hydrol 352:239-249

Medellín-Azuara J, Harou JJ, Olivares MA et al (2008) Adaptability and adaptations of California's water supply system to dry climate warming [J]. Clim Change 87(Supply):75-90

Middelkoop H, Daamen K, Gellens D et al (2001) Impact of climate change on hydrological regimes and water resources management in the Rhine basin. Clim Change 49:105-128

Ren LL, Wang MR, Li CH (2002) Impacts of human activity on river runoff in the northern area of China. J Hydrol 261:204-217

Rogers P, de Silva R, Bhatia R (2002) Water is an economic good: how to use prices to promote equity, efficiency, and sustainability. Water Policy 4:1-17

Rosegrant W (1997) Water resources in the twenty-first century: challenges and implications for action. International Food Policy Research Institute (IFPRI), Washington, DC

Savenije H, van der Zaag P (2002) Water as an economic good and demand management paradigms with pitfalls. Water Int 27(1):98-104

Stephenson D (1999) Demand management theory. Water SA 25(2):115-122

Wang G, Zhang J, He R (2006) Impacts of environmental change on runoff in Fenhe river basin of the middle Yellow River. Adv Water Sci 17(6):853-858

Wang X, Cai H, Zhang X et al (2008) Analysis on the seasonal drying up causes of Kuye River [J]. Resources Science 30(3):475-480, In Chinese

Wang X, Cai H, Zhang X (2009a) Analysis of changing characteristics and tendency of runoff and sediment transport in Huangfuchuan River watershed. Res Soil Water Conserv 16(1):222-226

Wang X, Zhang J, Liu J, et al (2009) Water demand management instead of water supply management: a case study of Yulin City in northwestern China, Proceedings of JS. 3 at the Joint IAHS \& IAH Convention, Hyderabad, India, September 2009. IAHS Publ. 330,340-346

Wang X, Zhang J, Wang G, et al (2010a) Climate change and water management adaptation for China, Xth Kovacs Colloquium, Paris, France, July, 2010. IAHS Publ. 338, 258-260

Wang X, Zhang J, Liu J, et al (2010b) Water resources planning and management based on system dynamics: a case study of Yulin city. Environment, Development and Sustainability

Yu LS (2006) The Huanghe (Yellow) River: recent changes and its countermeasures. Cont Shelf Res 26:2281-2298

Zhang H (2005) Strategic study for water management in China [M]. Southeast University Press, Nanjing

Zhang J, Zhang S, Wang J (2007) Study on runoff trends of the six larger basins in China over the past 50 years. Adv Water Sci 18(2):230-234 